\title{
A new fossil species of Procellaria (Aves: Procellariiformes) from the Pliocene of New Zealand
}

\author{
Alan James Drummond Tennyson ${ }^{1,3}$ \& Barbara Mizumo Tomotani ${ }^{1,2,4}$ \\ 1 Museum of New Zealand Te Papa Tongarewa. Wellington, New Zealand. \\ 2 Netherlands Institute of Ecology (NI00-KNAW), Department of Animal Ecology. Wageningen, Netherlands. \\ ${ }^{3}$ ORCID: http://orcid.org/0000-0001-6374-6924. E-mail: alant@tepapa.govt.nz \\ ${ }^{4}$ ORCID: http://orcid.org/0000-0002-8855-4803. E-mail: babi.mt@gmail.com
}

\begin{abstract}
We describe a new Procellaria petrel species from the late Pliocene of Taranaki, New Zealand. The new species is most similar morphologically to the White-Chinned Petrel (P. aequinoctialis), Spectacled Petrel (P. conspicillata) and the Westland Petrel (P. westlandica). Compared with those taxa, the new species has a deeper and shorter premaxilla, longer coracoid and shorter wings, while its legs are a similar size. Today, New Zealand is the centre of global diversity of the genus, with four breeding species. This is the first fossil species of Procellaria to be described from New Zealand, attesting to a reasonably long history of this genus in the region.
\end{abstract}

Keywords. Procellaria altirostris sp. nov.; Petrel; Piacenzian; Procellariidae; Taranaki.

\section{INTRODUCTION}

New Zealand is a global centre of diversity for seabirds today, however this contrasts with its sparse pre-Pleistocene fossil record - while penguins are well represented, other seabirds are not (Gill et al., 2010) - so the history of seabirds in the region is poorly understood. For instance, Procellariiformes are presently the most diverse group of seabirds in New Zealand (Gill et al., 2010), but only three fossil pre-Pleistocene taxa are described: a Pliocene albatross (Mayr \& Tennyson, 2020) and a shearwater (Tennyson \& Mannering, 2018), both from Taranaki, and a Miocene diving petrel from St Bathans (Worthy et al., 2007).

The Pliocene outcrops in the Taranaki region continue to produce a rich and globally significant fauna of marine vertebrates, including cetaceans, seals, fishes and other birds, the latest being a new species of penguin (McKee, 1994; Thomas et al., 2020). Here we describe the latest discovery from Taranaki: a new procellariiform species.

\section{MATERIAL AND METHODS}

The new fossil was identified as a bird from the Procellaria genus and thus compared with all liv- ing members of this genus: White-Chinned Petrel ( $P$. aequinoctialis Linnaeus, 1758), Spectacled Petrel ( $P$. conspicillata (Gould, 1844)), Westland Petrel (P. westlandica Falla, 1946), Grey Petrel (P. cinerea (Gmelin, 1789)), and Black Petrel (P. parkinsoni G.R. Gray, 1862).

We measured 155 skeletons of Procellaria spp. deposited in the collections of the Museum of New Zealand Te Papa Tongarewa, Wellington, New Zealand (NMNZ) and the Museu de Zoologia da Universidade de São Paulo, São Paulo, Brazil (MZUSP). In order to compare the measurements of the different species with the fossil, we only measured beaks from skulls where the ramphotecal plates were removed. Thus, the total sample size for individual measurements varies. For the principal component analysis (see below), we only used individuals that had all measurements, thus the PCA only includes a single $P$. conspicillata specimen. The primary comparative specimens used are listed in Appendix 1.

We took the following skeletal measurements (also see Fig. 1): skull minimum interorbital width; premaxilla maximum length from nasal hinge to tip, depth at the middle of the apertura nasi ossea, width at the middle of the apertura nasi ossea; coracoid maximum omal-sternal length; humerus maximum length, maximum proximal dorso-ventral width, maximum distal dorso-ventral width, mid-shaft dorso-ventral 

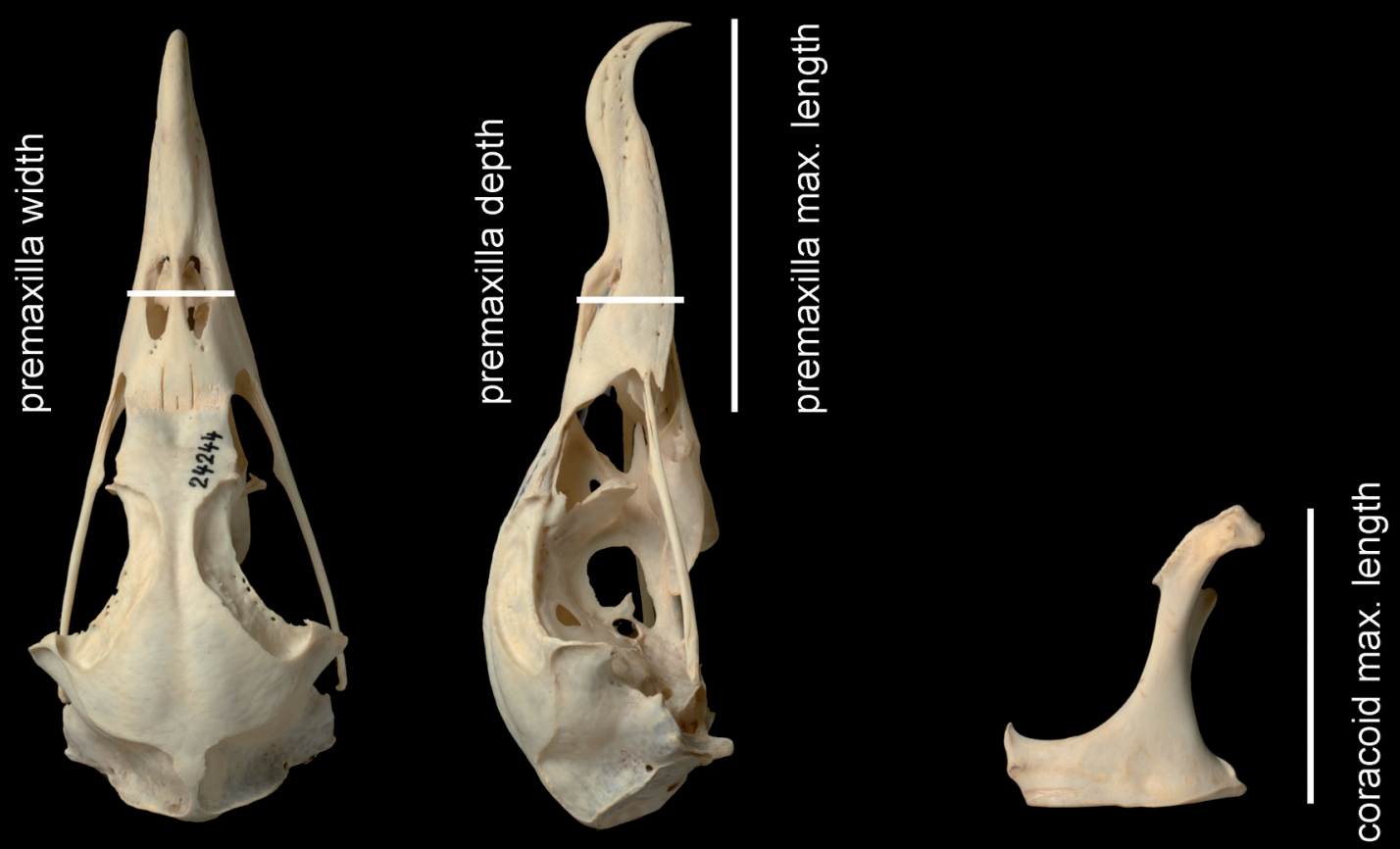

humerus proximal width
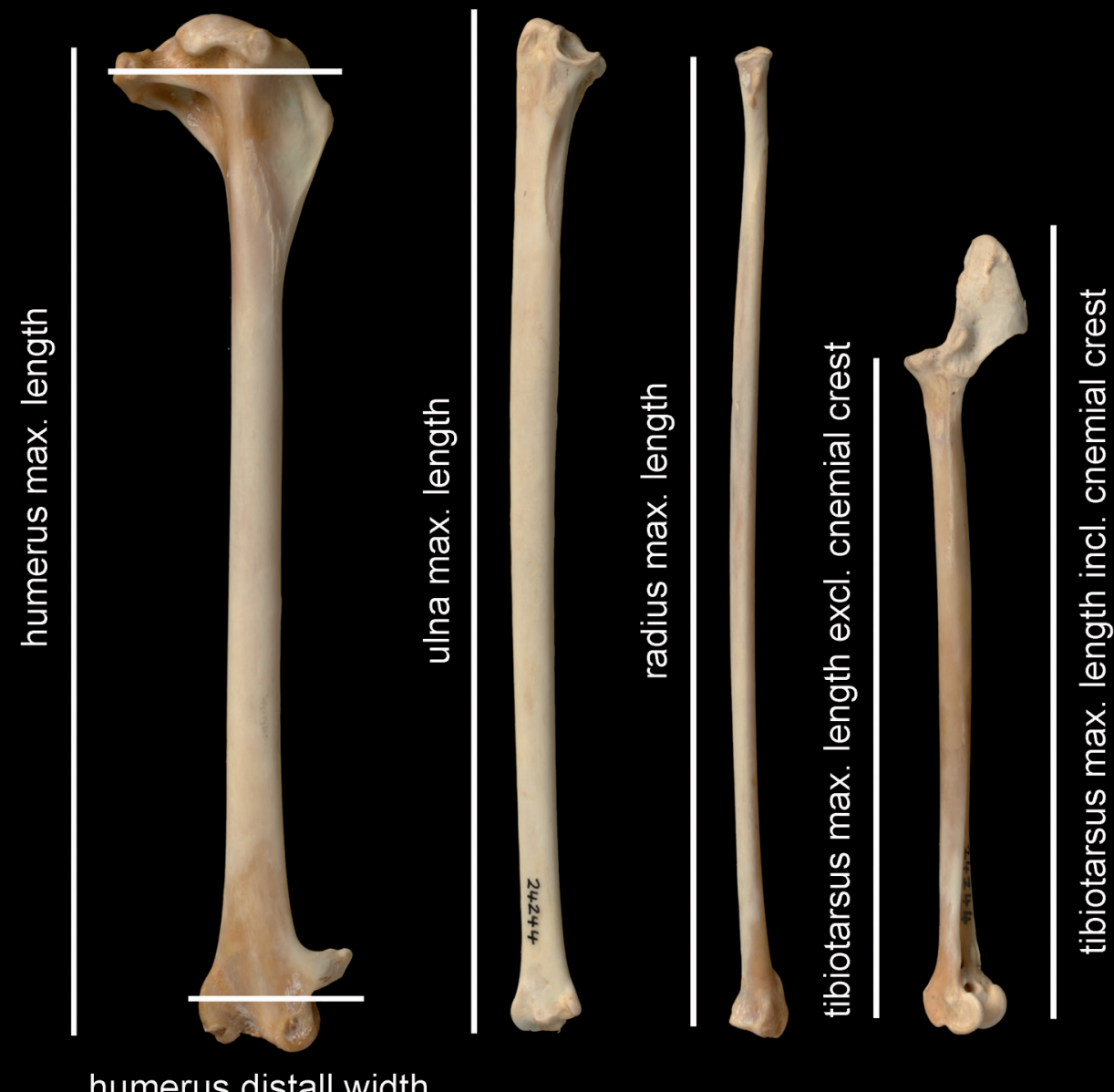

humerus distall width

\section{$5 \mathrm{~cm}$}

Figure 1. Plate illustrating how each bone element was measured. 
width; ulna maximum length; radius maximum length; femur maximum length; tibiotarsus maximum length including cnemial crest, maximum length excluding cnemial crest; tarsometatarsus maximum length. Osteological nomenclature follows Baumel \& Witmer (1993). All measurements were taken using vernier digital calipers (precison $0.01 \mathrm{~mm}$ ) or a ruler (precision $0.1 \mathrm{~mm}$ ) when skeletal elements were larger than $150 \mathrm{~mm}$.
Analyses were carried out in $\mathrm{R}$ version 3.6.1 (R Core Team, 2017). Firstly, measurements were compared using descriptive statistics (mean, standard error and measurement range). Then, we carried out a principal component analysis (PCA) on the z-standardized measurements (mean centred at 0 and standard deviation at 1) that allowed us to detect whether the fossil would cluster together with one of the other species.

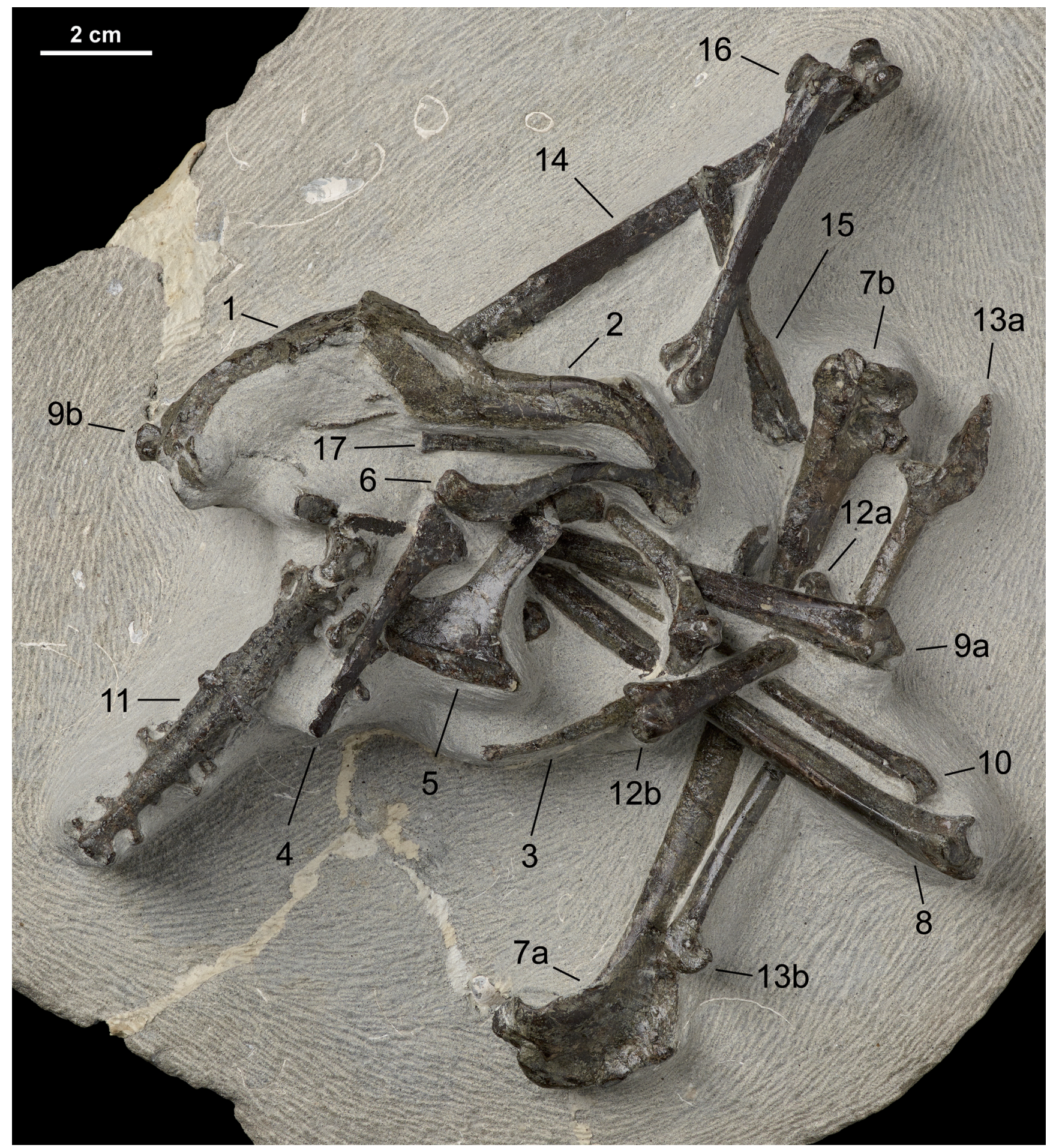

Figure 2. Pliocene fossil petrel Procellaria altirostris sp. nov., holotype NMNZ S.46691. Photo: Jean-Claude Stahl (Te Papa). (1) cranium; (2) premaxilla; (3) furcula; (4) right scapula; (5) left coracoid; (6) right coracoid; (7a) proximal right humerus; (7b) distal right humerus; (8) left ulna; (9a) proximal right ulna; (9b) distal right ulna; (10) right radius; (11) synsacrum; (12a) proximal left femur; (12b) distal left femur; (13a) proximal left tibiotarsus; (13b) distal left tibiotarsus; (14) right tibiotarsus; (15) left tarsometatarsus; (16) right tarsometatarsus; (17) pedal phalange. 


\section{RESULTS \\ Systematic Palaeontology \\ Order Procellariiformes Fürbringer, 1888 \\ Family Procellariidae Leach, 1820 \\ Procellaria Linnaeus, 1758 \\ Procellaria altirostris sp. nov. http://zoobank.org/urn:Isid:zoobank. org:act:093F56E5-D07E-44C3-8E75-059C486CB222}

Etymology: From the unusually deep premaxilla in comparison to other members of the Procellaria genus.

Holotype: NMNZ S.46691; partial skeleton embedded, but largely exposed, in a concretion. Elements preserved: partial cranium (crushed) with premaxilla, furcula, both coracoids, right scapula, right humerus, both ulnae, right radius, synsacrum, left femur, both tibiotarsi, both tarsometatarsi but the left is missing both ends, one pedal phalange, and other fragments. The fossil is from a fully grown individual based on bone ossification (Fig. 2).

Type Locality, Type Horizon and Age: Ohawe Beach, south Taranaki, North Island, New Zealand (New Zealand Fossil Record Electronic Database Number Q21/F0175, Fig. 3). The fossil was found inside a marine mudstone concretion loose on the beach in 2015, and prepared by John Buchanan-Brown in the same year. The concretion is presumed to have eroded from an adjacent cliff in the Tangahoe Formation. This Formation is 3.0-3.4 Ma (local Waipipian stage, late Pliocene, Piacenzian; McKee, 1994; Naish et al., 2005; Thomas et al., 2020). Such concretions

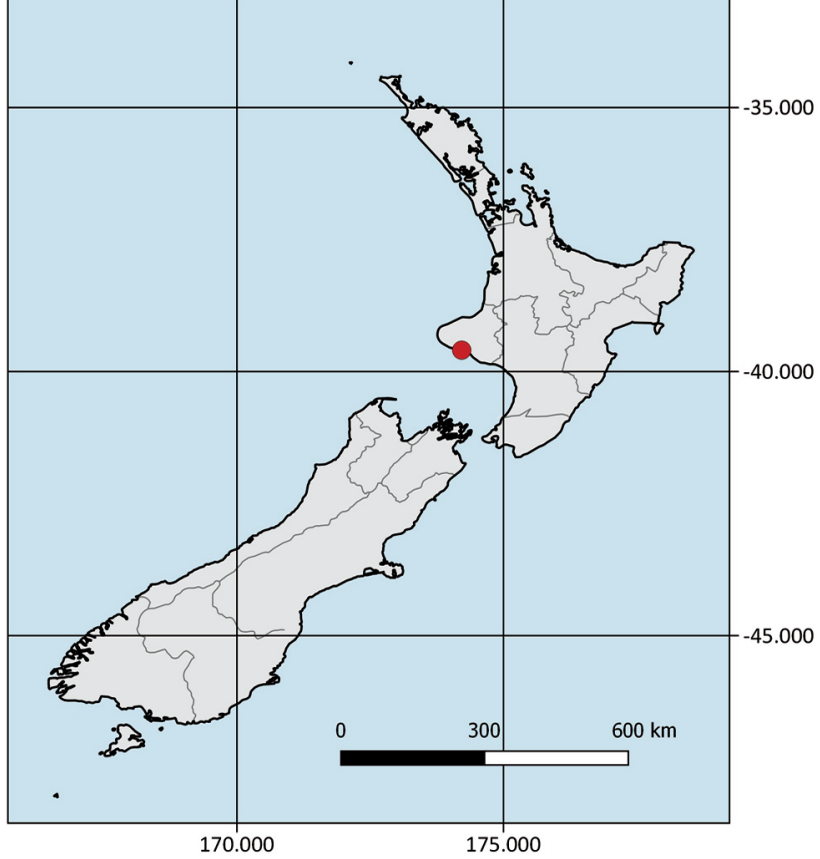

Figure 3. General location in Taranaki where the fossil was found.

are thought to have formed on the ocean floor at a depth of up to $50 \mathrm{~m}$ or more (Tennyson \& Mannering, 2018).

Generic attribution: Procellaria altirostris sp. nov. is referred to Procellaria because it is a large petrel falling in the size range of Procellaria species and outside the size range of every other recent genus in Procellariiformes: all recent Diomedeidae are larger and all Hydrobatidae and Pelecanoididae are smaller. Within the family

Table 1. Measurements (in $\mathrm{mm}$ ) of skeletal elements of the holotype of $P$. altirostris sp. nov., compared with measurements of other Procellaria species. For measurement details, see Methods.

\begin{tabular}{|c|c|c|c|c|c|c|}
\hline Measurement & NMNZ S.46691 & P. aequinoctialis & P. westlandica & P. conspicilata & P. cinerea & P. parkinsoni \\
\hline \multicolumn{7}{|l|}{ skull } \\
\hline min. intraorbital width & 15 & $14.24 \pm 0.09(50)$ & $14.4 \pm 0.12(35)$ & $13.57 \pm 0.22(7)$ & $13.76 \pm 0.10(37)$ & $11.4 \pm 0.15(16)$ \\
\hline \multicolumn{7}{|l|}{ premaxilla } \\
\hline max. length & 55.56 & $62.22 \pm 0.34(32)$ & $59.62 \pm 0.36(29)$ & $57.22(1)$ & $57.15 \pm 0.26(37)$ & $49.48 \pm 0.57(15)$ \\
\hline depth & 14.52 & $11.96 \pm 0.08(34)$ & $12.12 \pm 0.11(34)$ & $11.95(1)$ & $9.95 \pm 0.07(38)$ & $9.81 \pm 0.13(17)$ \\
\hline width & 13.5 & $13.76 \pm 0.13(34)$ & $14.7 \pm 0.17(34)$ & $14.23(1)$ & $12.42 \pm 0.13(38)$ & $11.98 \pm 0.21(17)$ \\
\hline \multicolumn{7}{|l|}{ coracoid } \\
\hline max. length & 41.99 & $37.93 \pm 0.20(27)$ & $39.12 \pm 0.15(33)$ & $38.92 \pm 0.86(2)$ & $36.15 \pm 0.15(35)$ & $33.35 \pm 0.28(17)$ \\
\hline \multicolumn{7}{|l|}{ humerus } \\
\hline max. length & 143.22 & $150.71 \pm 0.62(29)$ & $149.65 \pm 0.48(37)$ & $151.22 \pm 1.59(4)$ & $136.76 \pm 0.44(37)$ & $130.06 \pm 0.74(17)$ \\
\hline proximal width & 32.26 & $32.34 \pm 0.16(29)$ & $32.37 \pm 0.15(37)$ & $31.77 \pm 0.36(4)$ & $30.54 \pm 0.15(37)$ & $28.19 \pm 0.17(17)$ \\
\hline distal width & 17.68 & $17.49 \pm 0.07(29)$ & $17.12 \pm 0.08(36)$ & $17.77 \pm 0.22(4)$ & $16.4 \pm 0.05(37)$ & $15.04 \pm 0.10(18)$ \\
\hline shaft width & 7.44 & $7.58 \pm 0.05(28)$ & $7.44 \pm 0.05$ (37) & $7.38 \pm 0.07(4)$ & $7.41 \pm 0.05(37)$ & $6.52 \pm 0.06(18)$ \\
\hline \multicolumn{7}{|l|}{ ulna } \\
\hline max. length & 138.53 & $151.13 \pm 0.50(29)$ & $149.91 \pm 0.50(37)$ & $149.84 \pm 0.67(4)$ & $135.09 \pm 0.47(36)$ & $131.29 \pm 0.84(18)$ \\
\hline \multicolumn{7}{|l|}{ radius } \\
\hline max. length & 132.95 & $147.57 \pm 0.53(29)$ & $146.33 \pm 0.52(36)$ & $146.08 \pm 0.37(4)$ & $131.51 \pm 0.45(36)$ & $128.19 \pm 0.81(18)$ \\
\hline \multicolumn{7}{|l|}{ femur } \\
\hline max. length & 50.05 & $50.64 \pm 0.30(28)$ & $50.9 \pm 0.22(31)$ & $50.52 \pm 0.67(4)$ & $48.62 \pm 0.24$ (34) & $42.28 \pm 0.48(16)$ \\
\hline \multicolumn{7}{|l|}{ tibiotarsus } \\
\hline max. length incl. cnemial crest & 116.56 & $114.01 \pm 0.52(27)$ & $111.86 \pm 0.40(31)$ & $114.48 \pm 0.65(4)$ & $109.94 \pm 0.35(32)$ & $94.89 \pm 0.70(14)$ \\
\hline max. length excl. cnemial crest & 99.53 & $99.5 \pm 0.40(30)$ & $96.94 \pm 0.33(35)$ & $99.43 \pm 0.69(4)$ & $95.54 \pm 0.33(35)$ & $82.36 \pm 0.67(14)$ \\
\hline \multicolumn{7}{|l|}{ tarsometatarsus } \\
\hline max. length & 64.82 & $65.99 \pm 0.31(30)$ & $63.65 \pm 0.26(34)$ & $65.33 \pm 0.16(4)$ & $61.66 \pm 0.22(35)$ & $54.53 \pm 0.45(15)$ \\
\hline
\end{tabular}


A)

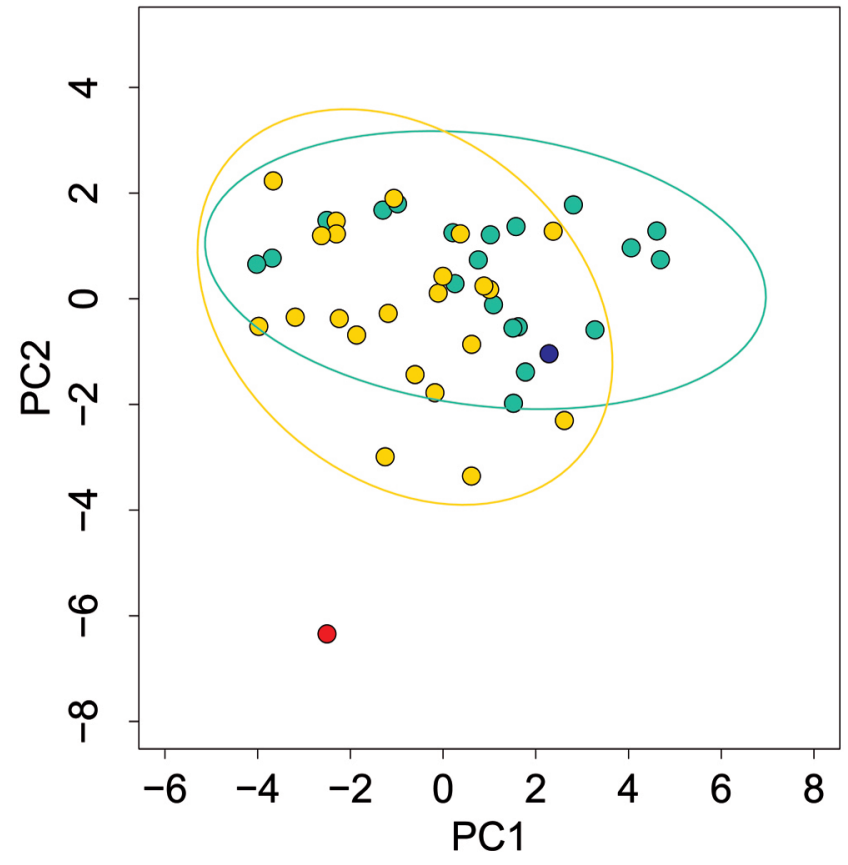

B)

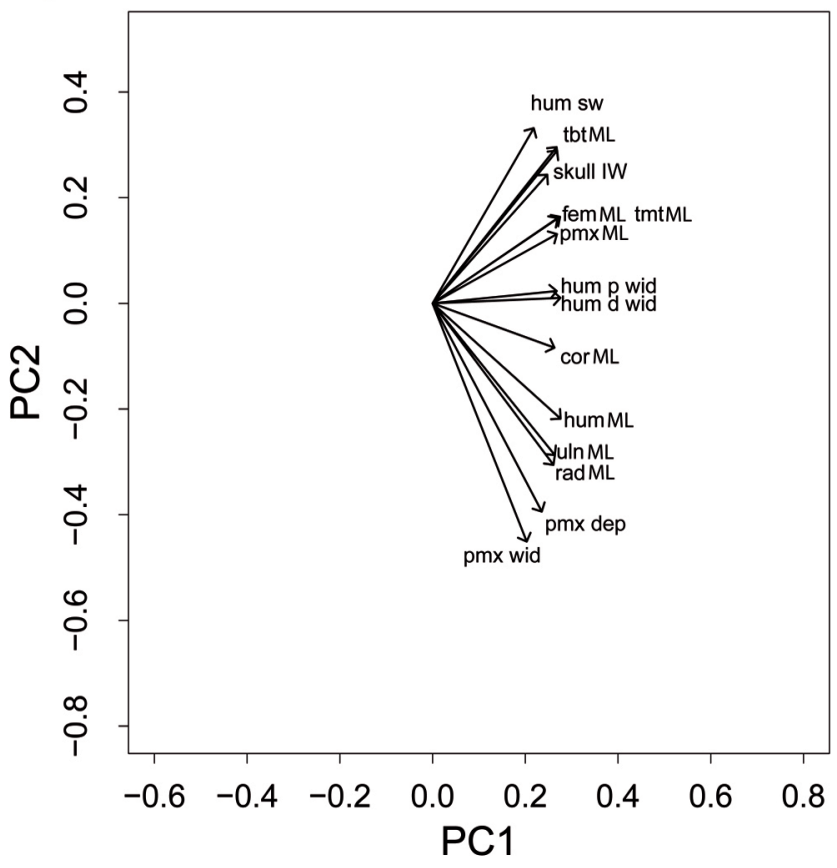

Figure 4. Principal component analysis for the skeletal measurements of the three Procellaria species that are most similar in morphology to the new species: $P$. aequinoctialis, $P$. conspicillata and $P$. westlandica. (A) Biplot of the first and second principal component scores. (B) Projection of the principal component vectors (loadings) of the tested parameters onto the PC1-PC2 biplot. Colours represent the different species: $P$. aequinoctialis $=$ green; $P$. conspicillata $=$ blue; $P$. westlandica $=$ yellow; P. altirostris sp. nov. $=$ red.

Procellaridae, birds in the Procellaria genus are the largest, with the exception of Macronectes Richmond, 1905, which is similar in size to some albatross taxa. Based on the narrow and deep beak, the strongly hooked premaxilla and the prominent pila supranasalis, the genus Procellaria can be easily distinguished from almost all other genera within the Procellaridae; the exceptions being Pterodroma Bonaparte, 1856 and Pseudobulweria Mathews, 1936. Generally, Pterodroma taxa have a narrower and shorter beak than Procellaria taxa; moreover, as in all Procellaria, the fossil has a longer humerus than ulna, while Pterodroma taxa have longer ulnae than humeri (Tennyson \& Mannering, 2018). The apertura nasi ossea of Pseudobulweria is smaller than in Procellaria taxa; moreover, the proximal end of the humerus of Pseudobulweria taxa lack the tubercle on the cranial surface of the ventral margin in the bicipital area (Tennyson \& Mannering, 2018). The shape of the apertura nasi ossea and this humeral tubercle of the fossil are features found in Procellaria taxa (Tennyson \& Mannering, 2018).

Differential diagnosis: Procellaria altirostris sp. nov. is identified as a member of the Procellariiformes by the beak having a sharply hooked tip, lateral furrows rostral of the nostrils (nasolabial grooves) and marked supraorbital fossae for nasal glands (fossa glandulae nasalis), i.e., salt glands.

Procellaria altirostris sp. nov. is most similar to the White-Chinned Petrel ( $P$. aequinoctialis), Spectacled Petrel $(P$. conspicillata) and Westland Petrel $(P$. westlandica). Compared with these taxa, the new species has a deeper and shorter premaxilla, a larger coracoid and shorter wings, while its legs are a similar size. It is slightly larger than the Grey Petrel ( $P$. cinerea) and notably larger than the Black Petrel (P. parkinsoni). The Grey Petrel also differs in having a more slender beak (width and depth relative to length) than all other members of the genus. Procellaria species show minor sexual dimorphism in size, with males averaging a little larger (Marchant \& Higgins, 1990; Warham, 1990). However, regardless of the sex of the fossil, it still falls outside the range of variation seen in other species (Table 1, Fig. 2, Fig. 4, Appendix 2).

\section{Measurements: see Table 1, Fig. 1.}

Distribution: The holotype is the only known specimen of Procellaria altirostris sp. nov. All members of the genus Procellaria travel thousands of kilometres at sea when foraging and/or migrating (Brooke, 2004), so we expect that Procellaria altirostris sp. nov. had similar behaviours and would have ranged widely in the seas around proto - New Zealand and probably been a long-distance migrant like other members of this genus (Brooke, 2004).

\section{DISCUSSION}

The discovery of a well-preserved specimen of a Procellaria petrel from the Pliocene adds important new knowledge about the history of this genus. Only two previous studies have identified this genus in Pliocene deposits and those were disarticulated remains: a single partial humerus from the early Pliocene of South Africa (Olson, 1985a) and three bones from the early Pliocene of North Carolina, USA (Olson \& Rasmussen, 2001). No older fossils of the genus are known (Olson, 1985b). Otherwise 
only much younger (Holocene) fossils have been documented (e.g., Tennyson, 2020; Worthy \& Jouventin, 1999).

This lack of a good fossil record for the genus has impaired more detailed analyses of its evolution. Our description of a Pliocene Procellaria provides further evidence to support the phylogeny proposed by Penhallurick \& Wink (2004), which suggested that crown-group Procellaria taxa were already present in the Miocene.

While we can only speculate on the functional significance of the minor skeletal differences between $P$. altirostris sp. nov. and other members of the genus, the fossil species probably had similar feeding strategies to living Procellaria. For example, surface feeding and shallow diving, with a diet consisting mainly of fishes, cephalopods and crustaceans (Brooke, 2004). When compared with other Procellaria, the relatively short wings, particularly the short ulna compared with the humerus length, suggest that it may have been less of a glider (Kuroda, 1955), perhaps using diving more often as a feeding strategy.

Finally, while New Zealand today is the worldwide centre of diversity for species of procellariiforms, including Procellaria (Dickinson \& Remsen, 2013), the new Pliocene fossil is the only evidence of Procellaria petrels being present in the country prior to the Late Pleistocene (Gill et al., 2010) and demonstrates a longer history for the genus in the region.

\section{ACKNOWLEDGMENTS}

We thank the collector, John Buchanan-Brown, for enabling the accession of this specimen into the NMNZ collection, and for preparing it; Luis Fabio Silveira and Rafael Nascimento (MZUSP) who hosted BMT at the MZUSP and assisted in locating specimens and retrieving their data; and Jean-Claude Stahl (NMNZ) for photographing NMNZ specimens. BMT was supported by a Rubicon fellowship of the Netherlands Organization for Scientific Research (NWO; Rubicon \#019.181EN.005).

\section{AUTHORS' CONTRIBUTION}

Conceptualization: A.J.D.T.; Investigation: A.J.D.T., B.M.T.; Formal analysis: B.M.T.; Writing - Original draft: A.J.D.T., B.M.T.; Writing - Review \& Editing: A.J.D.T., B.M.T.

\section{REFERENCES}

Baumel, J.J. \& Witmer, L.M. 1993. Osteologia. In: Baumel, J.J.; King, A.S.; Breazile, J.E.; Evans, H.E. \& van den Berge, J.C. (Eds.). Handbook of avian anatomy: nomina anatomica avium. Cambridge, Nuttall Ornithological Club. p. 45-132.
Brooke, M. 2004. Albatrosses and petrels across the world. 0xford, 0xford University Press.

Dickinson, E.C. \& Remsen, J.V. 2013. The Howard \& Moore complete checklist of the birds of the World. 4.ed. London, Edition. A. \& C. Black.

Gill, B.J.; Bell, B.D.; Chambers, G.K.; Medway, D.G.; Palma, R.L.; Scofield, R.P.; Tennyson, A.J.D.\&Worthy, T.H. 2010. Checklist of the birds of New Zealand, Norfolk and Macquarie Islands, and the Ross Dependency, Antarctica. Wellington, Te Papa Press.

Kuroda, N. 1955. On the osteology of the gadfly-petrels, Pterodroma. Annotationes Zoologicae Japonenses, 28: 171-177.

Marchant, S. \& Higgins, P.J. 1990. Handbook of Australian, New Zealand and Antarctic birds. Vol. 1: ratites to ducks. Melbourne, Oxford University Press.

Mayr, G. \& Tennyson, A.J.D. 2020. A small, narrow-beaked albatross from the Pliocene of New Zealand demonstrates a higher past diversity in the feeding ecology of the Diomedeidae. Ibis, 162(3): 723-734.

McKee, J. 1994. Geology and vertebrate palaentology of the Tangahoe Formation, South Taranaki Coast, New Zealand. Geological Society of New Zealand Miscellaneous Publications B, 80: 63-91.

Naish, T.R.; Wehland, F.; Wilson, G.S.; Browne, G.H.; Cook, R.A.;Morgans, H.E.G.; Rosenberg, M.; King, P.R.; Smale, D.; Nelson, C.S.; Kamp, P.J.J. \& Ricketts, B. 2005. An integrated sequence stratigraphic, palaeoenvironmental, and chronostratigraphic analysis of the Tangahoe Formation, southern Taranaki coast, with implications for mid-Pliocene (c. 3.4-3.0 Ma) glacioeustatic sea-level changes. Journal of the Royal Society of New Zealand, 35: 151-196.

Olson, S.L. 1985a. An early Pliocene marine avifauna from Duinefontein, Cape Province, South Africa. Annals of the South African Museum, 95: 147-164. Olson, S.L. 1985b. The fossil record of birds. Avian Biology, 8: 79-238.

Olson, S.L. \& Rasmussen, P.C. 2001. Miocene and Pliocene birds from the Lee Creek Mine, North Carolina. In: Ray, C.R. \& Bohaska, D.J. (Eds.). Geology and paleontology of the Lee Creek Mine, North Carolina, III. Washington, D.C., Smithsonian Institution Press. p. 233-365.

Penhallurick, J. \& Wink, M. 2004. Analysis of the taxonomy and nomenclature of the Procellariiformes based on complete nucleotide sequences of the mitochondrial cytochrome b gene. Emu, 104: 125-147.

Tennyson, A.J.D. 2020. Holocene bird bones found at the subantarctic Auckland Islands. Notornis, 67: 269-294.

Tennyson, A.J.D. \& Mannering, A.A. 2018. A new species of Pliocene shearwater (Aves: Procellariidae) from New Zealand. Tuhinga, 29: 1-19.

The R Project for Statistical Computing (R Core Team). 2017. R: A language and environment for statistical computing. Vienna, R Foundation for Statistical Computing.

Thomas, D.B.; Tennyson, A.J.D.; Scofield, R.P.; Heath, T.A.; Pett, W. \& Ksepka, D.T. 2020. Ancient crested penguin constrains timing of recruitment into seabird hotspot. Proceedings of the Royal Society B, 287: 20201497.

Warham, J. 1990. The petrels: their ecology and breeding systems. London, A. \& C. Black.

Worthy, T.H. \& Jouventin, P. 1999. The fossil avifauna of Amsterdam Island, Indian Ocean. Washington, D.C., Smithsonian Contributions to Paleontology, 89: 39-65.

Worthy, T.H.; Tennyson, A.J.D.; Jones, C.; McNamara, J.A. \& Douglas, B.J. 2007. Miocene waterfowl and other birds from central Otago, New Zealand. Journal of Systematic Palaeontology, 5: 1-39. 


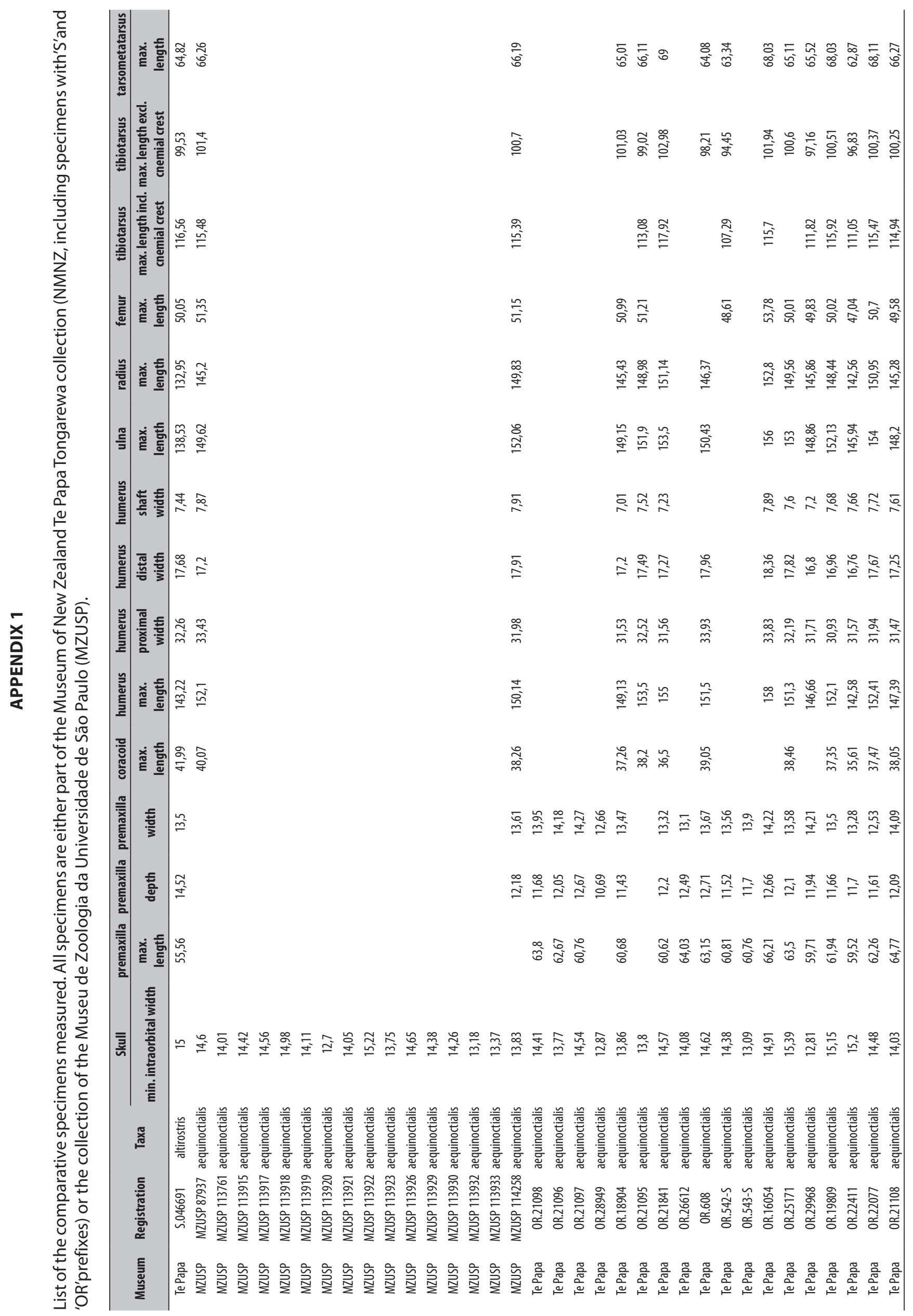




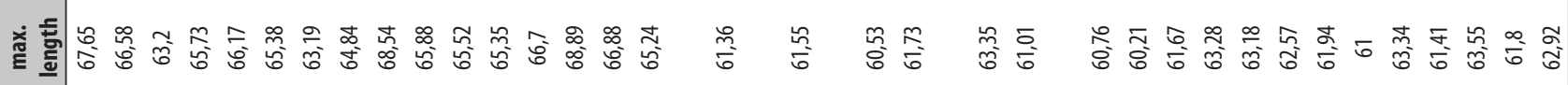
畜部

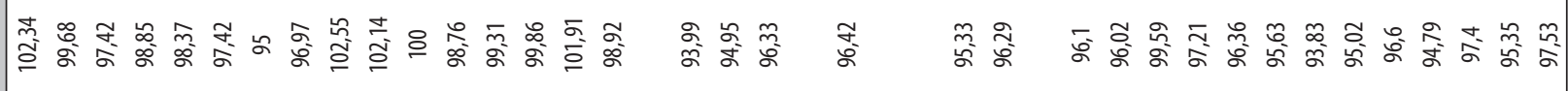

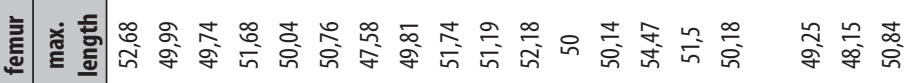

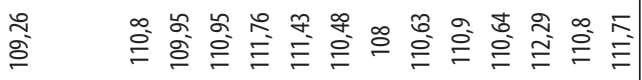

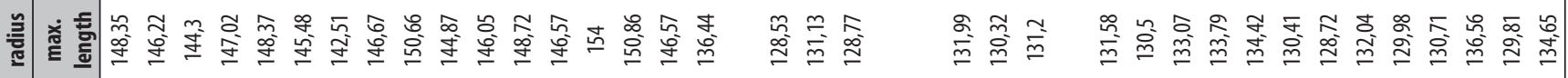

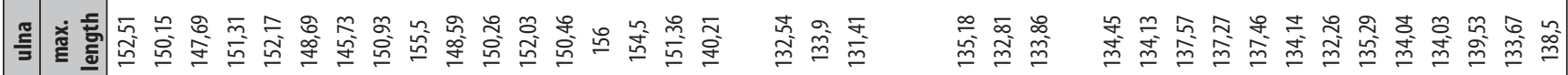

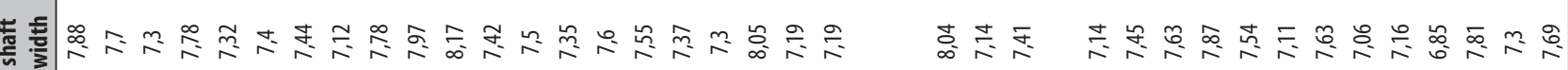

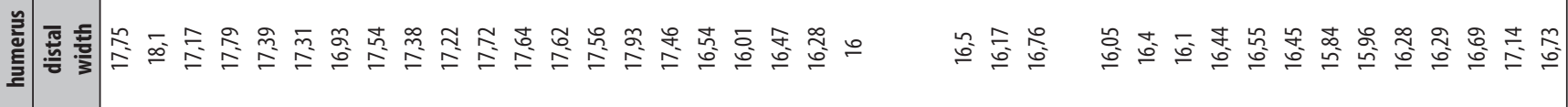

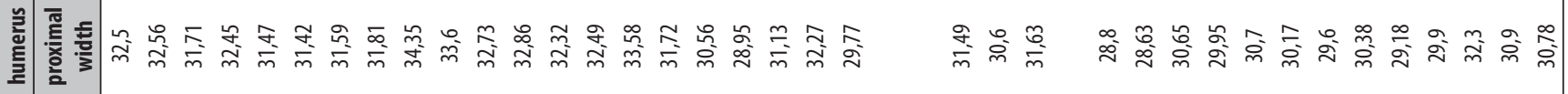

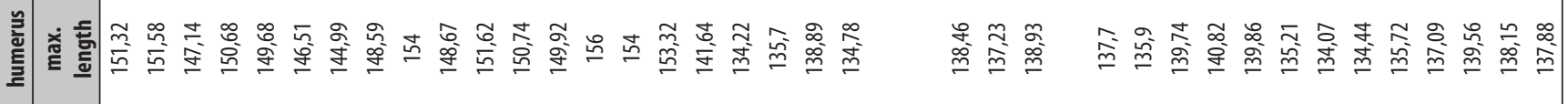

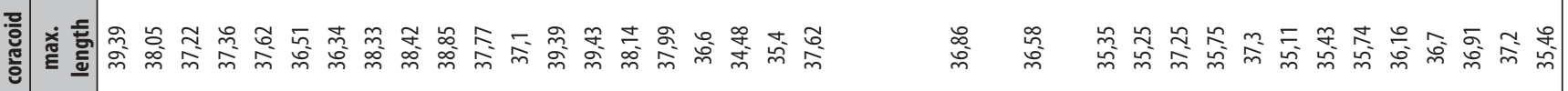

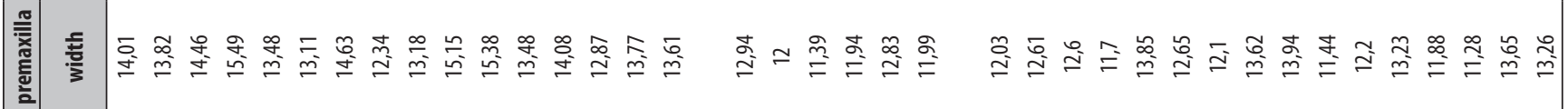

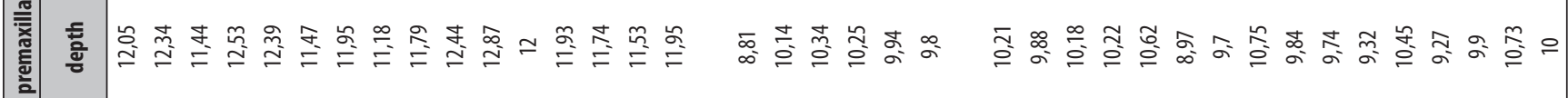

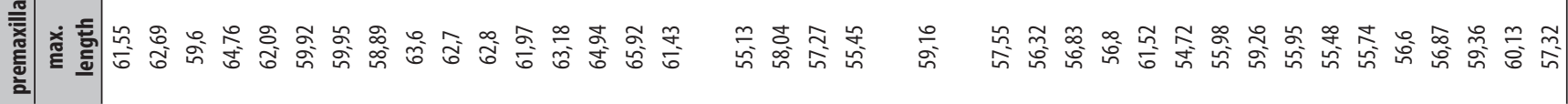

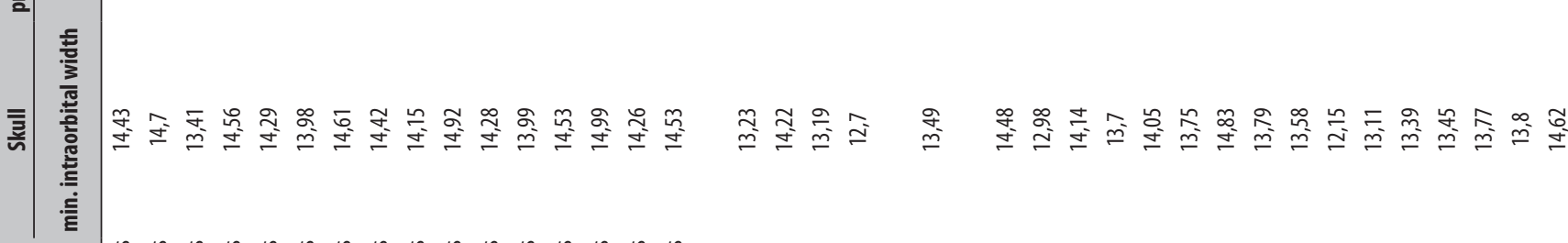

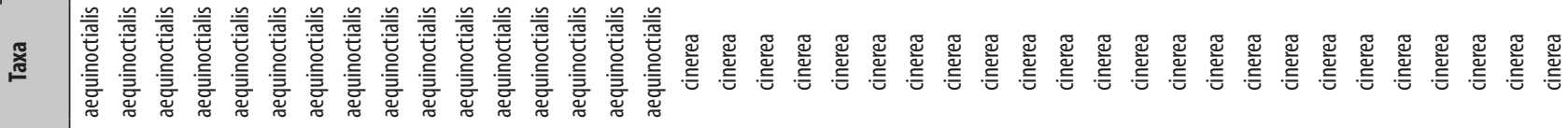

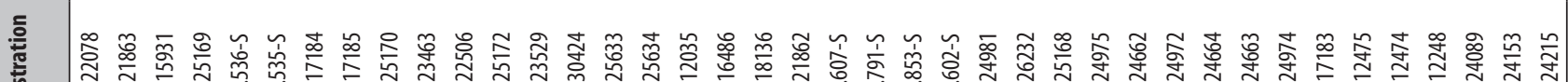

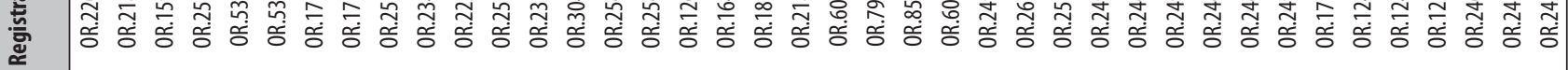

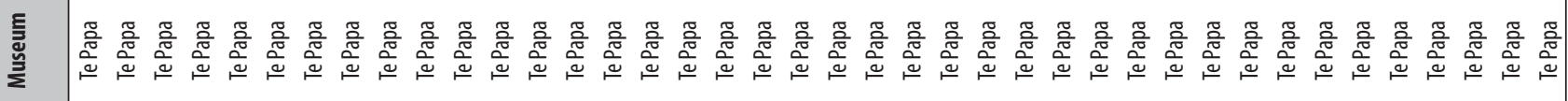




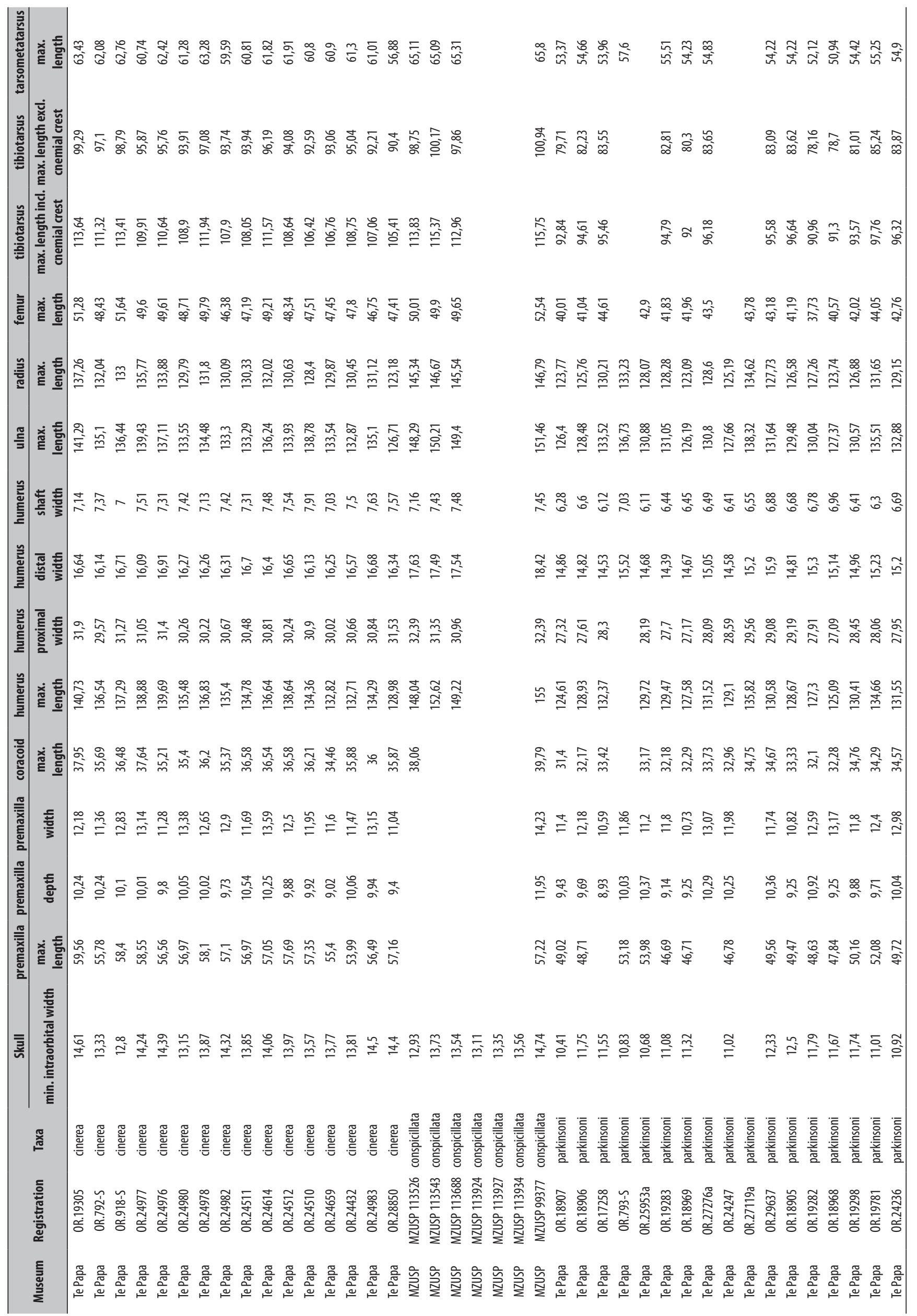




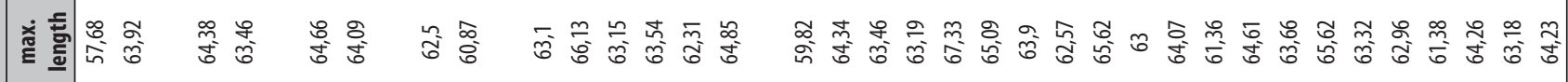
离

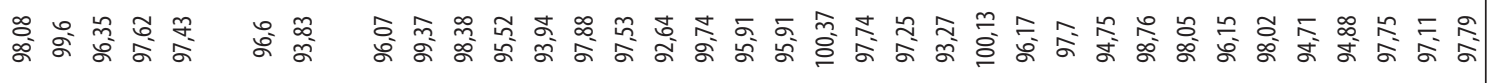

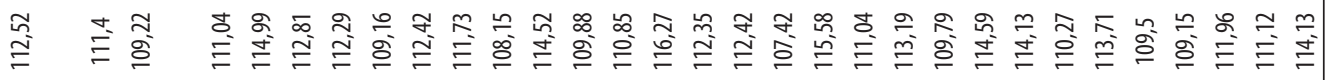

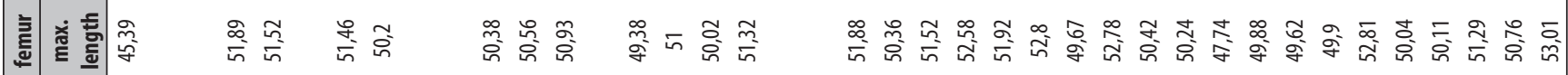

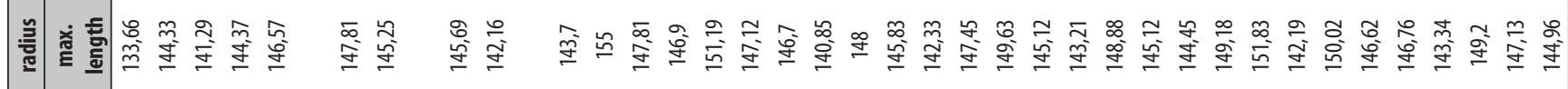

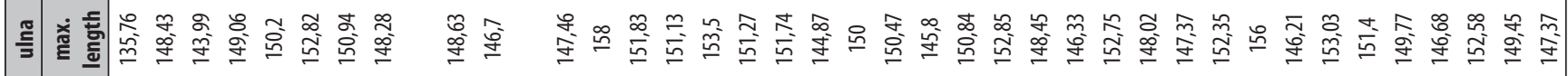

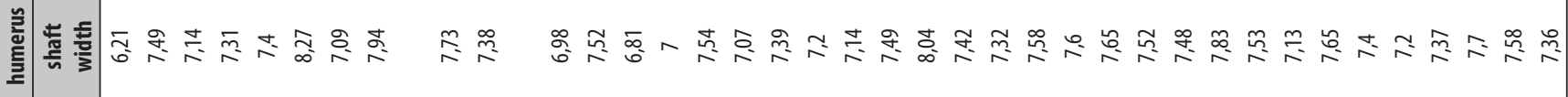

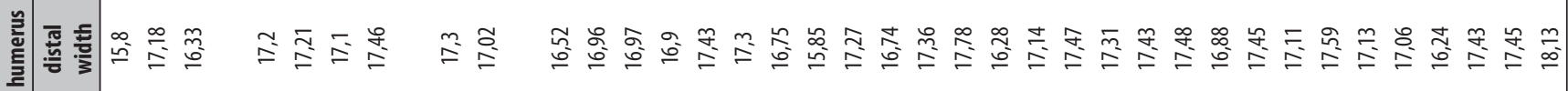

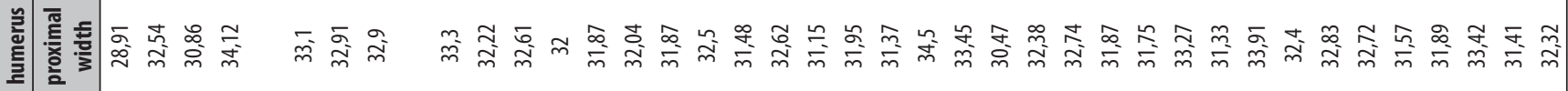

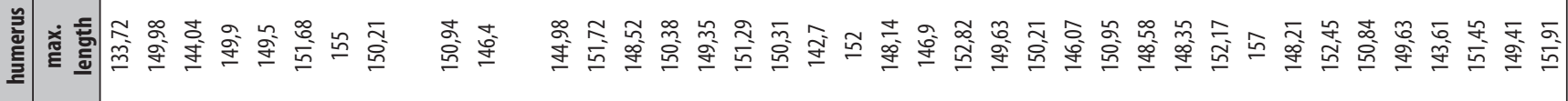

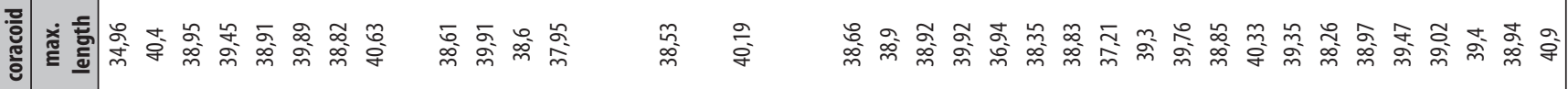

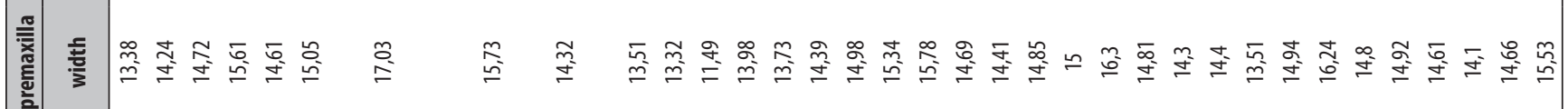

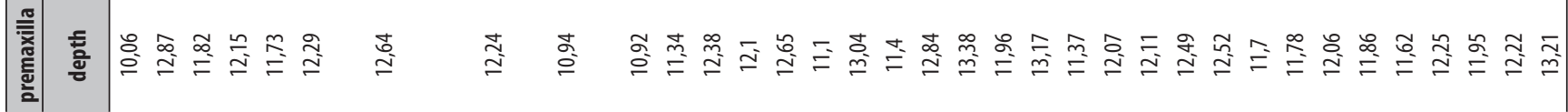

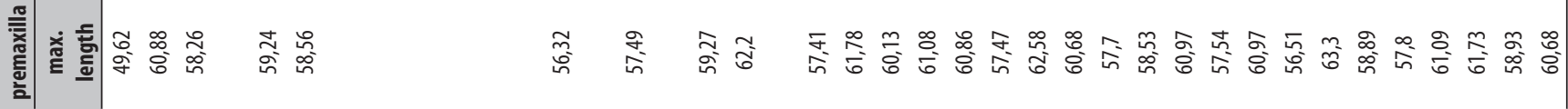

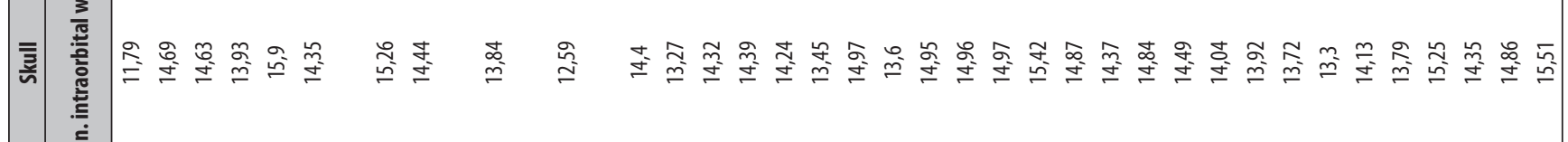

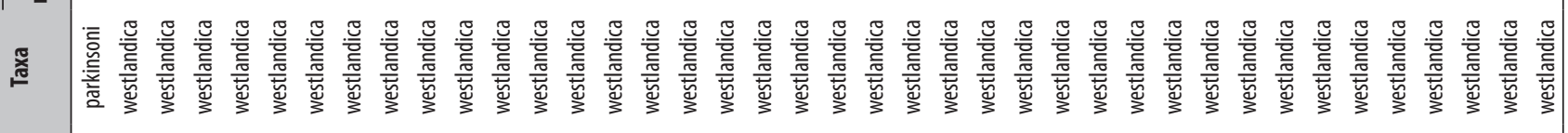

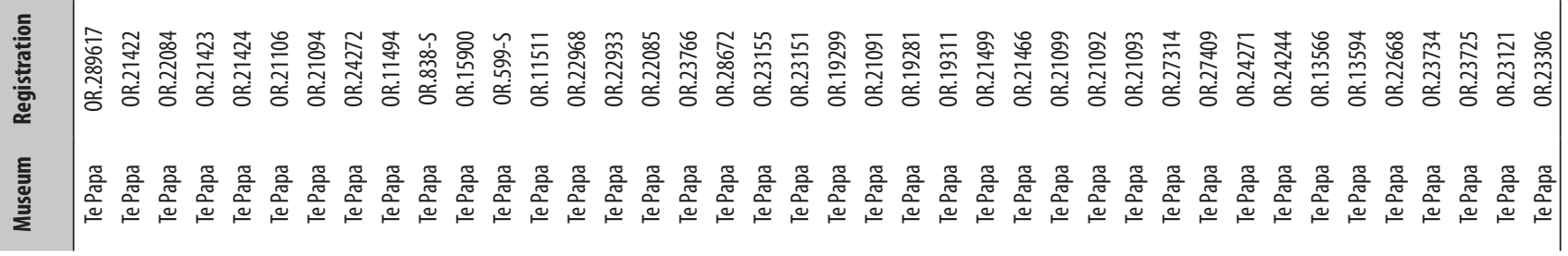




\section{APPENDIX 2}

Means (solid symbols) and standard errors (error bars) of each of the 15 skeletal measurements used for the fossil description for each Procellaria species. Open symbols represent the individual measurements. Colours represent different species: yellow $=P$. westlandica; blue $=P$. conspicillata; green $=P$. aequinoctialis; red $=P$. altirostris sp. nov.; orange $=P$. $c i$ nerea; pink $=$ P. parkinsoni .
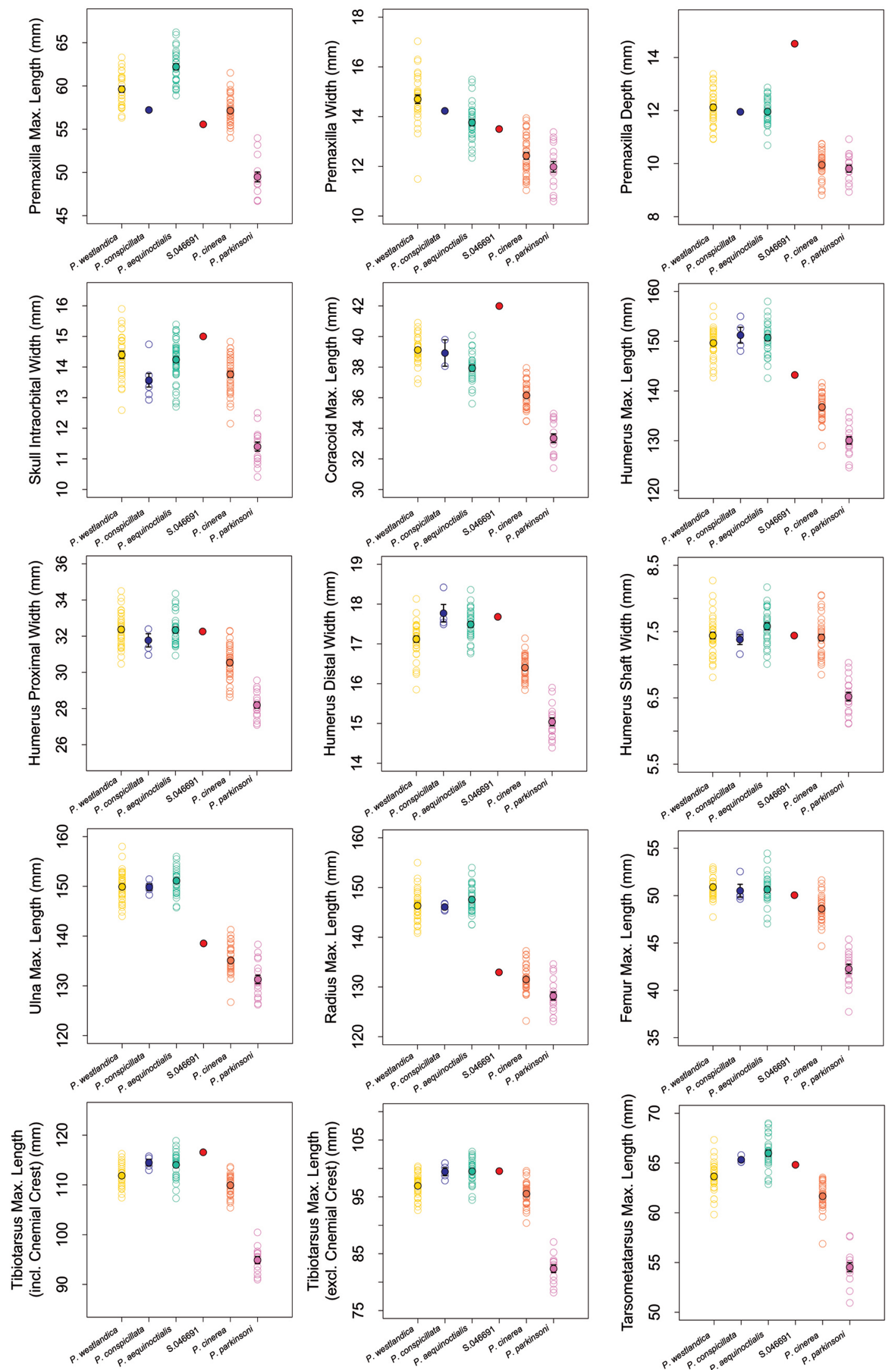